\title{
Differences of Financial Management Strategy of Central European and Russian Milk Processors
}

\author{
J. Špička ${ }^{1}$, S. R. Kontsevaya ${ }^{2}$ \\ ${ }^{1}$ University of Economics, Prague, Czech Republic \\ ${ }^{2}$ Russian Timiryazev State Agrarian University, Moscow, Russia
}

\begin{abstract}
The aim of this article is a detailed investigation of financial performance of milk processing companies of Central Europe and the Russian Federation before the Russian embargo. An investigated object is a data base of accounting reports of 5 countries over the period of $2009-2013$. The number of selected companies is 370 . The article also involves a short review of the dairy industry condition. In order to compare financial performance of two regions 4 types of criteria i.e. profitability ratios, turnover ratios, liquidity and capital structure were implemented. The differences between the Visegrad group and the Russian Federation were tested through Kolmogorov-Smirnov test at the significance level of 0.05 . The main difference between the financial performances is the following: profitability (ROCE) of Russian companies is 3 times higher than in the Central Europe, stock turnover ratio is 2 times lower in the Russian Federation, and credit period is 4 days shorter. Generally speaking, the key difference is higher profitability of Russian companies which may be associated with reduced cost component, different technology of production of dairy products as well as with different capital structure.
\end{abstract}

\section{Keywords}

Dairy industry, milk processing, financial analysis, controlling, statistical analysis.

Špička, J. and Kontsevaya, S. R. (2016) "Differences of Financial Management Strategy of Central European and Russian Milk Processors", AGRIS on-line Papers in Economics and Informatics, Vol. 8, No. 1, pp. 89 - 102. ISSN 1804-1930. DOI: 10.7160/aol.2016.080109.

\section{Introduction}

Milk processing industry is one of the most important branches in the food industry because milk and milk products are essential parts of the human diet. Consumption of milk is increasing all over the world (Gulaeva and Trystsina, 2010). Like the vast majority of raw material industries, viability of the dairy industry depends on its ability to adapt to some changes and minimize negative consequences. The successful adaptation of the dairy industry is critical to addressing the global challenge of providing a secure supply of food globally (Buys et al., 2014).

The dairy market largely lacks flexibility: neither producers, nor processing companies are able to respond to market changes at a proper pace. The bargaining position of the processing companies against producers is relatively strong (Rozsa, 2014). Taking managerial decisions on the basis of financial performance analysis of the industry is quite relevant to managers of companies belonging to the dairy industry (Kostina, 2009). There has been published only few investigations devoted to financial performance analysis in milk processing sector (Mejstř́iková and Mezera, 2011; Alborov et al., 2012; Rozsa, 2014).

The article concerns milk processors as the middle phase of the dairy vertical. They sell the production to retailers. Retailers are big international companies with strong bargaining power towards milk processors and milk producers. So, milk processors balance their economic position between suppliers and retailers. Moreover, European vertical of milk production and processing is influenced by the Common Agricultural Policy. Milk producers (farmers) are supported through direct and indirect operational subsidies. Farmers are not able to generate profits without current subsidies (Doubek et al., 2012; Foltínová and Špička, 2014). Milk processors are often medium and large companies which could be supported mainly by investment subsidies. However, more and more 
farmers start to build their own milk processing capacities. Having analyzed such companies in the work, Stephenson (2006) states that their financial conditions and profitability are similar with milk production companies. As a solution of the problem of low profitability, Donnellan and Keane (2015) propose transferring of milk producers to the countries with better climate conditions and less costs consequently.

Before the Russian embargo in 2014, there were quite significant trade flows with milk and milk products between the European Union and the Russian Federation. Import to export ratio of Russian foreign trade with milk and milk products decreased from $47.6 \%$ to $8 \%$ between 1991 and 2001. Then, it increased to $29.2 \%$ in 2011 (Svatoš et al., 2014). Russia has been a net importer of milk and milk products from the European Union. Currently, Russia wants to increase its self-sufficiency in agricultural commodities and food products. For example, it intends to increase the domestic self-sufficiency in milk and milk products from $80 \%$ to $90.2 \%$ by 2020 (Petrick, 2015) ${ }^{1}$. But the Russian dairy industry has faced many problems. A stabilisation in livestock numbers, improvement in the quality of milk, an increase in the marketability of milk from private farms, and the World Trade Organisation negotiations are important determinants for the future outlook of the Russian dairy sector (Turjansky et al., 2014). Since 2015, Russia changed priorities in the agricultural policy towards support of dairy genetics (Petrick, 2015). Alternatively, the European dairy market experienced deep economic crisis in 2008 and 2010 and currently it has to deal with the abolition of milk quotas and low prices. As it is still not possible to evaluate the impact of the Russian embargo on financial results of milk processors, we focus on the preembargo period to reveal differences in financial management and condition between the Central European and Russian milk processors.

Currently the market has been influenced by major dominant companies at the dairy market. For example, the Czech Republic has loose oligopoly competition in the milk processing market. Barring the leading market players, there is also a large number of small and medium companies so called "oligopoly hem" operating either on the whole market or regionally. The same situation is in Slovakia. Špička (2015)

${ }^{1}$ http://www.iamo.de/fileadmin/user_upload/Bilder_und Dokumente/06-veranstaltungen/icae-mailand_2015/ICAE_ symposion_Martin_Petrick/03_Petrick.pdf reveals that the biggest Polish milk processors are cooperatives unlike Czech and Slovak companies which are owned by one major national or foreign investor. A cooperative character of Polish milk processing companies means that they are more closely related to farmers - milk producers and can better deal with transfer pricing. The investigation of the dairy market in Hungary (Perekhozhuk et al., 2011) proves the fact that some major companies keep the biggest part of the market. It prevents the other companies in the dairy industry from normal development. The biggest Russian milk processors are groups owned by big foreign parent companies such as PepsicoInc. and Danone.

The aim of the article is to compare financial performance of the Central European and Russian milk processors in the period 2008 - 2013. It covers the period before the Russian embargo since there is a lack of data in 2014. However, authors plan to compare the corporate economic situation before and after the Russian embargo as soon as the individual financial statements will be available. The article involves the following key items:

1. The assessment of current condition of the dairy industry in the Central Europe and the Russian Federation is presented.

2. The description of the market concentration in milk and milk products in the Central Europe and the Russian Federation is presented.

3. Scientifically based statistical selection from accounting data of individual companies of milk processors in Central Europe and Russian Federation has been done.

4. Financial condition assessment of the dairy industry has been measured and the distributions of the financial indicators have been compared through a statistical hypothesis testing. A difference in the financial performance and its reasons has been identified.

\section{Material and methods}

The description of the dairy market in the region V4 and the Russian Federation was based on the official data from Eurostat, Faostat and national statistical offices. Region V4 represents the Visegrad group (Czech Republic, Slovakia, Poland and Hungary). The analysis of the market concentration followed data from Euromonitor International (Passport) 
database. The market was divided into three market segments of the milk processing industry: i) milk and drinking milk products, ii) yoghurt and sour milk products, and iii) cheese.

Since the differences in financial performance of milk processors in the Central Europe (V4 countries) and the Russian Federation are evaluated in the article, the individual data of milk processors from five countries were gained from Amadeus database. The database contains comparable harmonized accounting data of individual companies in all branches. We selected panel data from NACE Rev. 2 (Code C10.5) Manufacture of the dairy products with available accounting data in all years from the five-year period $2009-2013$. A basic dataset contains 176 companies from the Central Europe and 194 companies from the Russian Federation. The Table 1 describes the basic dataset by region. Size of a company is measured by turnover (operating revenues) and total assets in thousands EUR. Profit is measured by Earnings before Taxes (EBT) in thousands EUR.

\begin{tabular}{|l|c|c|c|c|c|}
\hline Russia & Obs & Mean & Std. Dev. & Min & Max \\
\hline Turnover & 194 & 29926.6 & 125145.1 & 88.49507 & 1533166 \\
\hline Assets & 194 & 18413.88 & 87006.63 & 52.93281 & 905851.2 \\
\hline EBT & 194 & 1180.954 & 6909.798 & -3548.823 & 92806.04 \\
\hline V4 & Obs & Mean & Std. Dev. & Min & Max \\
\hline Turnover & 176 & 38366.6 & 79348.72 & 146.3368 & 656532.3 \\
\hline Assets & 176 & 19530.71 & 62933.96 & 153.0361 & 755787.6 \\
\hline EBT & 176 & 756.842 & 3266.836 & -13953.93 & 35798.39 \\
\hline Total & Obs & Mean & Std. Dev. & Min & Max \\
\hline Turnover & 370 & 33941.3 & 105807.5 & 88.49507 & 1533166 \\
\hline Assets & 370 & 18945.13 & 76407.73 & 52.93281 & 905851.2 \\
\hline EBT & 370 & 979.2141 & 5484.415 & -13953.93 & 92806.04 \\
\hline
\end{tabular}

Source: Amadeus database, own calculation

Table 1: Key features of the basic dataset (thousands EUR).

To check the representativeness of the dataset, it was necessary to compare the sample with total population in each region. Table 2 provides facts about the share of the sample in total population and turnover in the Czech Republic (CZ), Slovakia (SK), Poland (PL), Hungary (HU) and the Russian Federation (RU).

\begin{tabular}{|l|r|r|}
\hline & \multicolumn{1}{|c|}{$\begin{array}{c}\text { Number } \\
\text { of companies }\end{array}$} & $\begin{array}{c}\text { Turnover, } \\
\text { thousands EUR }\end{array}$ \\
\hline CZ - sample & 29 & 1013.6 \\
\hline CZ - population & 178 & 1719 \\
\hline CZ - share (\%) & $\mathbf{1 6 . 2 9 \%}$ & $\mathbf{5 8 . 9 6 \%}$ \\
\hline PL - sample & 115 & 4547.5 \\
\hline PL - population & 523 & 7375.7 \\
\hline PL - share (\%) & $159 \%$ & $\mathbf{6 1 . 6 6 \%}$ \\
\hline SK - sample & 189 & 427.1 \\
\hline SK - population & $\mathbf{2 1 . 9 4 \%}$ & 653.6 \\
\hline SK - share (\%) & 17 & $\mathbf{6 5 . 3 5 \%}$ \\
\hline HU - sample & 106 & 764.3 \\
\hline HU - population & $\mathbf{1 6 . 0 4 \%}$ & 948.1 \\
\hline HU - share (\%) & 194 & $\mathbf{8 0 . 6 1 \%}$ \\
\hline RU - sample & 1192 & 5805760 \\
\hline RU - population & $\mathbf{1 6 . 2 7 \%}$ & 10751420 \\
\hline RU - share (\%) & & $\mathbf{5 5 . 9 9 \%}$ \\
\hline
\end{tabular}

Source: Eurostat, Amadeus database, own calculation

Table 2: Sample size in total population and turnover in 2013.

The comparison of the sample and the population shows that the sample represents quite low share of population but majority share of turnover. It means that the sample generally covers larger companies. So, the conclusions of the article can be generalized for the market leaders being not small milk processors.

The market concentration in the milk processing industry used $\mathrm{CR}_{4}$ indicator that calculates a sum of total market share of the four largest companies in the industry. Concentration ratios are usually used to show the extent of market control of the largest companies in the industry and to illustrate the degree to which an industry is oligopolistic. The $\mathrm{CR}_{4}$ ratio was calculated from company shares of sales value not from brand shares.

The financial performance of milk processors between the two regions is assessed through ten financial ratios. Since we used financial ratios, not absolute values, we have not solved the problem of local currencies and exchange rates. Moreover, the time period 2009 - 2013 facilitates data processing because the Russian rubble experienced strong depreciation in 2014. Following financial indicators were selected for comparison. The construction of financial indicators respects the ratios in the User Guide of the Amadeus database (Bureau van Dijk, 2015). They represent all important aspects of corporate financial performance. 
A) Profitability ratios

- Return on Capital Employed (ROCE, $\%)=($ Profit before tax + Interest paid $)$ $/$ (Shareholder funds + Non-current liabilities) * 100

- Return on Assets $(\mathrm{ROA}, \%)=$ (Profit before tax / Total assets) $* 100$

- Profit margin $(\%)=$ (Profit before tax / Operating revenue) $* 100$

B) Turnover ratios

- Stock turnover $(\mathrm{x})=$ Operating revenue/ Stocks

- Collection period (days) $=$ (Debtors/ Operating revenue) $* 360$

- Credit period (days) $=$ (Creditors/ Operating revenue) $* 360$

- Assets turnover $(\mathrm{x})=$ Operating revenue / Total Assets

C) Liquidity and capital structure

- Current ratio $(\mathrm{x})=$ Current assets $/$ Current liabilities

- Liquidity ratio $(\mathrm{x})=$ (Current assets - Stocks) / Current liabilities

- Solvency ratio (Asset based, \%) = (Shareholders funds / Total assets) * 100

- Gearing $(\%)=$ (Non-current liabilities + Loans) / Shareholders funds $* 100$

Each financial indicator was calculated as a mean of the period 2009 - 2013. It means that one value of each indicator per one company entered the statistical analysis.

The dataset passed through cleaning process. Outliers were detected separately for each indicator and region (V4, the Russian Federation) in order to prevent any distortions of statistical testing. So, the test for each financial indicator follows different number of observations. Outliers were detected and removed through visual assessment of box plot diagrams.

To test the differences between the two regions, tests of statistical hypotheses were applied. The appropriate choice of statistical test depends on results of normality distribution test and variance-comparison test. The Shapiro-Wilk normality test (S-W test) is based on Shapiro and Wilk (1965) with a new approximation accurate for $4 \leq \mathrm{n} \leq 2000$ (Royston, 1992). The Shapiro-Wilk test utilizes the null hypothesis principle to check whether a sample came from a normally distributed population. If the p-value of the Shapiro-Wilk test is less than the chosen alpha level $(\alpha=0.05)$, then the null hypothesis is rejected and there is evidence that the data tested are not from a normally distributed population.

The two-group variance-comparison test (V-C test) performs tests on the equality of standard deviations (variances). If the $\mathrm{p}$-value of the variance ratio test is less than the chosen alpha level $(\alpha=0.05)$, then the null hypothesis of equal variance between the two groups is rejected.

Since the results of assumption tests show that the data has mostly non-normal distribution and there are not equal variances of indicators between the two regions, we choose two-sample Kolmogorov-Smirnov test (K-S test) to determine if there are any differences in the distribution of variable for the two groups. K-S test, nonparametric tests of hypotheses, is fairly powerful for alternative hypotheses that involve lumpiness or clustering in the data. The directional hypotheses are evaluated with the statistics

$$
\begin{aligned}
& D^{+}=\max _{x}\{F(x)-G(x)\} \\
& D^{-}=\min _{x}\{F(x)-G(x)\} \\
& D=\max \left\{\left|D^{+}\right|,\left|D^{-}\right|\right\}
\end{aligned}
$$

Where $F(x)$ and $G(x)$ are the empirical distribution functions for the sample being compared. The p-value for this statistic may be obtained by evaluating the asymptotic limiting distribution. If the p-value of the K-S is less than chosen alpha level $(\alpha=0.05)$, there is a significant difference (one-side or two-side) between the two regions.

Let $m$ be the sample size for the first sample, and let $n$ be the sample size for the second sample. A corrected p-value was obtained by modifying the asymptotic p-value by using a numerical approximation technique:

$$
\begin{aligned}
& Z=\Phi^{-1}\left(P_{\alpha}\right)+1.04 / \min (m, n)+2.09 / \max (m, n) \\
& \quad-1.35 / \sqrt{m n /(m+n)} \\
& p-\text { value }=\Phi(Z)
\end{aligned}
$$

Where $\Phi($.$) is the cumulative normal distribution.$

Statistical tests were processed automatically in software Stata SE 12.

\section{Results and discussion}

Table 3 provides brief overview on the Russian and the Central European dairy sector.

In European countries, averagely a half of the area is used for agricultural needs and in the Russian 


\begin{tabular}{|l|r|r|r|r|r|}
\hline Categories & \multicolumn{1}{|c|}{ CZ } & \multicolumn{1}{c|}{ PL } & HU & \multicolumn{1}{c|}{ RU } & \multicolumn{1}{c|}{ SK } \\
\hline Country area, sq.km. & 78870 & 312680 & 93030 & 17098250 & 49030 \\
\hline Agricultural area, sq.km. & 42190 & 144100 & 53400 & 2168400 & 19280 \\
\hline Agricultural area, \% & 53.49 & 46.09 & 57.4 & 12.68 & 39.32 \\
\hline Number of cows, th. heads & 373 & 2361 & 256 & 7766 & 150 \\
\hline Number of cows, per 1sq.km. of agricultural area & 8.83 & 16.38 & 4.79 & 3.58 & 7.77 \\
\hline Production of milk, th tons & 2849 & 12718 & 1758 & 30286 & 959 \\
\hline $\begin{array}{l}\text { Implementation of milk (fresh milk for sale } \\
\text { for processing), th tons }\end{array}$ & 2358.42 & 9921.66 & 1364.23 & 19700 & 826.64 \\
\hline
\end{tabular}

Source: Faostat, clal.it, own calculation

Table 3: Assessment of the current state of the dairy industry of Russia and Central Europe (V4 countries) in 2013.

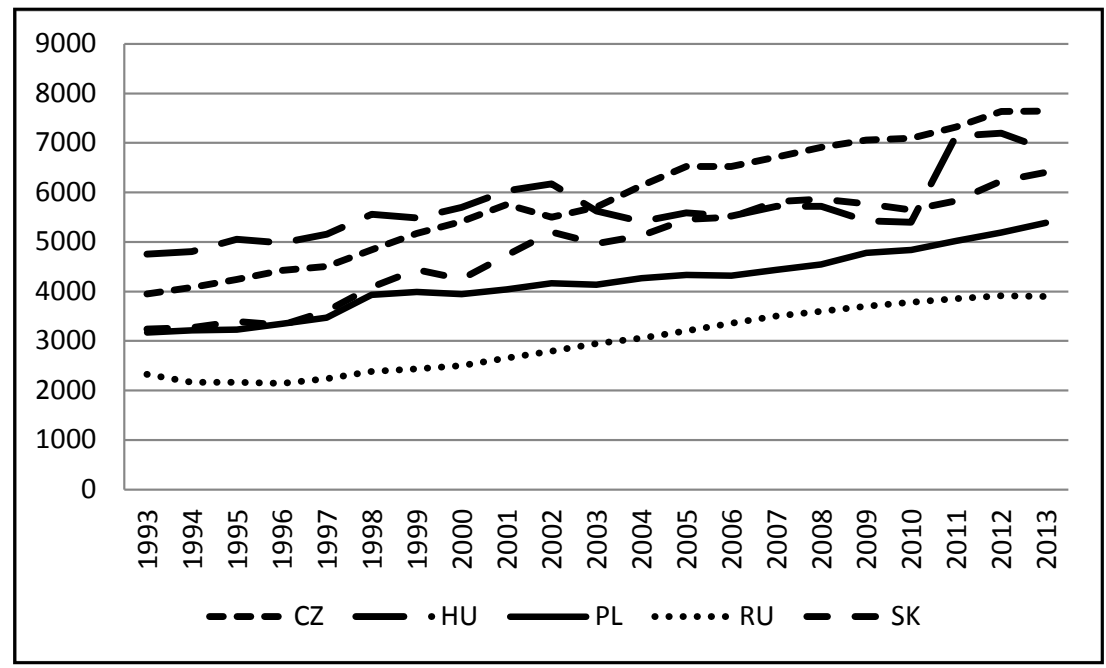

Source: Faostat, own calculation

Figure 1: Milk yield per cow kg per year (1993-2013) in 5 countries.

Federation the agricultural area is only $12.68 \%$. In spite of the fact, that the Russian Federation has the biggest number of cows (7 766 th.Heads), the number of cows per 1 sq. km. is the lowest (i.e. 3.58 cows). The biggest number of cows 16.38 th.heads per 1 sq. $\mathrm{km}$. is in Poland. It has the leading position in milk production in Europe 12718 th.tons.

Fig. 1 demonstrates the dairy cow production in 5 countries during 11 years. Milk yield per one cow has been increasing over the period and the Czech Republic (index 2013/1993=193.5) and Slovakia (index 2013/1993 =197.8) keep leading position. In 2013, the average milk yield was $7644 \mathrm{~kg} /$ cow in the Czech Republic. The third rank in the dynamic of the milk yield had Poland with $70.1 \%$ increase from 1993 to 2013. The lowest milk yield was $3900 \mathrm{~kg} / \mathrm{cow}$ in the Russian Federation (index 2013/1993 =167.4). Low livestock yield in the Russian Federation is caused by insignificant number of high-producing brood cows in a core herd and poor conditions of material and technical facilities of the agriculture. Poor climate conditions do not significantly influence low milk yield currently. For instance Finland is the country with poor climate conditions having the milk yield $8222 \mathrm{~kg} / \mathrm{cow}$. Overall increase of the milk yield in all countries was caused by nutrition improvement and welfare conditions. The welfare improvement has been supported by investment subsidies in the EU countries.

Import and export of milk is presented in Table 4. It obviously has quite big share in overall milk production. There are a lot of transnational companies among milk processors. This initial point of interest clearly highlights the importance of this research.

The Czech Republic and Poland are milk exporters. Their export is two or three times bigger than import. In Slovakia and Hungary export is approximately equal to import. In the Russian Federation import is about 18 times more than export. Quantitatively, the Russian Federation produces and imports 


\begin{tabular}{|l|c|c|c|c|c|}
\hline & $\mathrm{CZ}$ & $\mathrm{PL}$ & $\mathrm{HU}$ & \multicolumn{1}{c|}{ SK } & \multicolumn{1}{c|}{ RU } \\
\hline Import & 665.32 & 1113.74 & 442.08 & 455.23 & 5206.59 \\
\hline Export & 1459.99 & 3484.47 & 504.24 & 494.74 & 280.356 \\
\hline Balance & 794.67 & 2370.73 & 62.16 & 39.51 & -4926.234 \\
\hline
\end{tabular}

Source: Faostat, clal.it, own calculation

Table 4: Foreign trade - milk and milk products expressed in milk equivalent in 2013 (th.tonnes).

milk most of all countries and its export of milk is the least one among other countries. It may be concluded that the Russian Federation, being the biggest milk producer, does not satisfy internal needs in milk and it has to purchase milk abroad. At the same time other investigated countries in Europe produce enough milk and export it.

Since the market concentration affects the profits of the market players, the concentration ratio of the four biggest companies $\left(\mathrm{CR}_{4}\right)$ has been measured in four Central European countries in 2011 and 2014 to see changes in time.

\begin{tabular}{|l|c|c|c|}
\hline Country & $\begin{array}{c}\text { Drinking milk } \\
\text { products }\end{array}$ & $\begin{array}{c}\text { Yoghurt and sour } \\
\text { milk products }\end{array}$ & Cheese \\
\hline Czech Republic & 37.26 & 47.59 & 46.12 \\
\hline Poland & 62.92 & 64.69 & 46.5 \\
\hline Slovakia & 68.6 & 66.68 & 53.77 \\
\hline Hungary & 53.98 & 56.62 & 57.28 \\
\hline Russia & 56.66 & 51.1 & 17.15 \\
\hline
\end{tabular}

Source: Faostat, clal.it, own calculation

Table 5: Concentration ratio of the milk processing industry in $2013(\%)$.

The concentration analysis shows that Russian markets as well as Central European markets (except the Czech Republic) are highly concentrated. The market has a character of oligopoly. The cheese market in Russia is highly fragmented since Russian consumption of cheese is highly dependent on imports.

The specific feature of Polish milk processors is that there are strong cooperatives like SM Mlekpol, SM Mlekovita and OSM Lowicz. They are the biggest and most modern dairy cooperative operated in Poland and the top dairy processors in Europe. The cooperative character offers specific supplier-customer relations. It brings the dairy industry in profitable position by comparison with other countries because the transfer prices between producers and processors are set differently. In other Central European countries, the cooperative character of milk processors is not usual. The conditions in the Czech Republic are so that efficient dairy cooperatives may be established (Ratinger and Bošková, 2013). However, establishment of the cooperatives requires modification of traditional mode of farmers' cooperation. Currently farmers are not completely ready for dairy cooperatives. The important aspect here is negative experience in establishment of such cooperatives in past though in the end of $19^{\text {th }}$ century and in the beginning of $20^{\text {th }}$ century there were efficient agricultural cooperatives in the Czech Republic and Slovakia. The situation about agricultural cooperatives in Poland is quite different. Since $19^{\text {th }}$ century and before World War II agrarian cooperation traditions were very strong in Poland. After communists being in, the cooperatives were saved but became more bureaucratic and subordinated to the government. In fact they lost their functions. Then the cooperatives were recreated after capitalists being in. Unfortunately the cooperatives cannot be recreated soon. It takes time to establish the relations and links. Agricultural cooperatives in Poland are not so strong as in Denmark and Norway (Chloupková et al., 2003).

In order to complete the picture of the market structure in selected countries, the following part lists the major market players in 2013.

The Czech Republic:

- Drinking milk products: Madeta a.s., Olma a.s., Mlékárna Kunín a.s., Bohemilk a.s.

- Yoghurt and sour milk products: Danone a.s., Olma a.s., Zott s.r.o., Mlékárna Kunín a.s.

- Cheese: Madeta a.s., Pribina s.r.o., Lactalis CZ s.r.o., Bel Sýry Česko a.s.

Poland:

- Drinking milk products: SM Mlekpol, SM Mlekovita, Jeronimo Martins Polska SA, OSM Lowicz.

- Yoghurt and sour milk products: Danone Sp zoo, Bakoma Sp zoo, Zott Polska Sp zoo, Jeronimo Martins Polska SA.

- Cheese: Hochland Polska Sp zoo, SM Mlekovita, SM Mlekpol, Mleczarnia Turek Sp zoo. 
Slovakia:

- Drinking milk products: Rajo a.s., Tatranská Mliekareň a.s., Coop Jednota Slovensko s.d., Tesco Stores SR a.s.

- Yoghurt and sour milk products: Rajo a.s., Senoble Central Europe s.r.o., Danone a.s., Milk-Agro spol. s.r.o.

- Cheese: Milex NMNV a.s., Syráreň Bel Slovensko a.s., Levické Mliekárne a.s., Milsy a.s., Bánovce nad Bebravou.

Hungary:

- Drinking milk products: Sole-Mizo Zrt, Alföldi Tej Értékesítoés Beszerzo Kft, Friesland Campina Hungária Zrt, TescoGlobál Áruházak Zrt.

- Yoghurt and sour milk products: Danone Kft, Sole-Mizo Zrt, Zott Hungária Kft, Alföldi Tej Értékesítoés Beszerzo Kft.

- Cheese: Pannontej Zrt, Sole-Mizo Zrt, Tolnatej Zrt, Óvártej Zrt.

Russia:

- Drinking milk products: Danone Russia Group of Cos, Wimm-Bill-Dann Produkty Pitania OAO, Magnit OAO, Molvest ZAO.

- Yoghurt and sour milk products: Danone Industriya OOO, Wimm-Bill-Dann Produkty Pitania OAO, Danone Russia Group of Cos, Molvest ZAO.

- Cheese: Valio St Petersburg ZAO, Hochland Russland OOO, Lactalis Vostok ZAO, Wimm-Bill-Dann Produkty Pitania OAO.

ROCE is a first indicator that was calculated in the two regions. It is the important indicator of profitability. It explains how much profit does the company generate from long-term own and external capital employed. So, it is the important indicator for investors. Table 6 contains results of assumptions tests and K-S test.

The statistical test clearly shows that ROCE of milk processors in Russia is significantly higher than in the Visegrad group. The expected return of capital depends on inflation. In Russia there was $9 \%$ inflation officially and $15-20 \%$ unofficially over a period of $2009-2013^{2}$. Business in Russia is associated with high risks. High ROCE provides confidence to owners since the higher risk the higher ROCE should be.

Another explanation of the difference results from the capital structure. When we compare ROCE indicator that contains shareholders' funds and long-term debt with ROA indicator which calculates with the total capital (short-term and long-term), we can identify differences in the structure of the capital employed. Russian milk processors has higher share of long-term liabilities and loans to shareholder funds. They have also higher costs of interests paid. It is clearly demonstrated by the indicator gearing in Table 7 . Big volume of the long-term capital in Russia is caused by snowballing increase of credits in $2009-2013$.

Table 8 presents ROA. It measures the profit gained from one monetary unit of total assets (i. e. shortterm and long-term assets). In other words, ROA gives an idea as to how efficient management is at using its assets to generate earnings.

ROA is higher in Russia than in the Visegrad group. However, the difference is not as big as in ROCE. From one hand a high value of ROCE may seem attractive to the investors and demands investments of money. However, big value of ROCE points at big volume of long-term capital as well but not

\footnotetext{
${ }^{2}$ Source: www.gks.ru
}

\begin{tabular}{|c|c|c|c|c|c|}
\hline S-W test & Obs & $\mathbf{W}$ & $\mathbf{V}$ & $\mathbf{z}$ & p-value \\
\hline RU & 179 & 0.96006 & 5.412 & 3.863 & 0.0001 \\
\hline V4 & 154 & 0.97964 & 2.423 & 2.009 & 0.0223 \\
\hline $\mathrm{V}-\mathrm{C}$ test & Mean & Std. Err. & Std. Dev. & \multicolumn{2}{|c|}{ [95\% Conf. Interval] } \\
\hline RU & 24.421 & 1.416 & 18.939 & 21.628 & 27.215 \\
\hline V4 & 7.454 & 0.55 & 6.83 & 6.367 & 8.542 \\
\hline \multicolumn{2}{|c|}{ Ratio $=\operatorname{sd}(\mathrm{RU}) / \mathrm{sd}(\mathrm{V} 4)$} & \multicolumn{4}{|c|}{ H0: ratio $=1 ;$ HA: ratio $!=1 ; p$-value $=0.0000$} \\
\hline K-S test & D & p-value & corrected & \multicolumn{2}{|c|}{ Significance $(\alpha=0.05)$} \\
\hline RU & 0.0112 & 0.98 & - & \multicolumn{2}{|c|}{-} \\
\hline V4 & -0.5378 & 0 & - & \multicolumn{2}{|c|}{$\mathrm{RU}>\mathrm{V} 4$} \\
\hline Combined & 0.5378 & 0 & 0 & \multicolumn{2}{|c|}{$\mathrm{RU} \neq \mathrm{V} 4$} \\
\hline
\end{tabular}

Source: Amadeus database, own calculation

Table 6: Statistical tests of ROCE (\%). 


\begin{tabular}{|c|c|c|c|c|c|}
\hline S-W test & Obs & $\mathbf{W}$ & $\mathbf{V}$ & $\mathbf{z}$ & p-value \\
\hline RU & 172 & 0.87666 & 16.144 & 6.351 & 0.00000 \\
\hline V4 & 151 & 0.89092 & 12.765 & 5.775 & 0.00000 \\
\hline $\mathrm{V}-\mathrm{C}$ test & Mean & Std. Err. & Std. Dev. & \multicolumn{2}{|c|}{ [95\% Conf. Interval] } \\
\hline RU & 177.006 & 12.425 & 162.958 & 152.479 & 201.533 \\
\hline V4 & 47.267 & 3.134 & 38.510 & 41.075 & 53.459 \\
\hline \multicolumn{2}{|c|}{ Ratio $=\mathrm{sd}(\mathrm{RU}) / \mathrm{sd}(\mathrm{V} 4)$} & \multicolumn{4}{|c|}{$\mathrm{H} 0:$ ratio $=1 ; \mathrm{HA}$ : ratio $!=1 ; \mathrm{p}$-value $=0.0000$} \\
\hline K-S test & D & p-value & corrected & \multicolumn{2}{|c|}{ Significance $(\alpha=0.05)$} \\
\hline RU & 0.0058 & 0.995 & - & \multicolumn{2}{|c|}{-} \\
\hline V4 & -0.4643 & 0.000 & - & \multicolumn{2}{|c|}{$\mathrm{RU}>\mathrm{V} 4$} \\
\hline Combined & 0.4643 & 0.000 & 0.000 & \multicolumn{2}{|c|}{$\mathrm{RU} \neq \mathrm{V} 4$} \\
\hline
\end{tabular}

Source: Amadeus database, own calculation

Table 7: Statistical tests of gearing (\%).

\begin{tabular}{|c|c|c|c|c|c|}
\hline S-W test & Obs & W & $\mathbf{V}$ & $\mathbf{z}$ & p-value \\
\hline RU & 173 & 0.97287 & 3.569 & 2.906 & 0.00183 \\
\hline V4 & 164 & 0.97344 & 3.336 & 2.744 & 0.00303 \\
\hline $\mathrm{V}-\mathrm{C}$ test & Mean & Std. Err. & Std. Dev. & \multicolumn{2}{|c|}{ [95\% Conf. Interval] } \\
\hline RU & 4.575 & 0.481 & 6.327 & 3.625 & 5.524 \\
\hline V4 & 3.316 & 0.33 & 4.224 & 2.665 & 3.967 \\
\hline \multicolumn{2}{|c|}{ Ratio $=\operatorname{sd}(\mathrm{RU}) / \mathrm{sd}(\mathrm{V} 4)$} & \multicolumn{4}{|c|}{$\mathrm{H} 0$ : ratio $=1 ; \mathrm{HA}$ : ratio $!=1 ; \mathrm{p}$-value $=0.0000$} \\
\hline K-S test & D & p-value & corrected & \multicolumn{2}{|c|}{ Significance $(\alpha=0.05)$} \\
\hline RU & 0.0591 & 0.555 & - & \multicolumn{2}{|c|}{ - } \\
\hline V4 & -0.1471 & 0.026 & - & \multicolumn{2}{|c|}{$\mathrm{RU}>\mathrm{V} 4$} \\
\hline Combined & 0.1471 & 0.052 & 0.04 & \multicolumn{2}{|c|}{$\mathrm{RU} \neq \mathrm{V} 4$} \\
\hline
\end{tabular}

Source: Amadeus database, own calculation

Table 8: Statistical tests of the ROA (\%).

at extra profitability. It is reasonable hypothesis for Russia and proved by below calculations of ROA and profit margin which values do not extremely differs in Russia and in Europe. ROA depends on profit margin and assets turnover. So, both indicators are tested in following parts of the article.

Profit margin is expressed as a percentage and, in effect, measures how much out of every monetary unit of sales a company actually keeps in earnings. It is strongly affected by input-output efficiency, price setting and cost management. Table 9 compares profit margin in the Visegrad group and the Russian Federation.

Higher ROA (and ROCE) can be explained by significantly higher profit margin of Russian milk processors against V4 group. It means that Russian milk processors gain more profit from one unit of sales.

In the Russian Federation high profit margin is obtained due to cost management mainly. Large milk processing companies with well- developed management system are transnational (e.g. Pepsico). However, decreasing the operating costs on milk products plays a big role. Fresh milk is bought for the low price from a manufacturer. Then, different cost-cutting inputs, such as a palm oil, a milk powder and others are implemented in manufacturing process to make the products cheaper. Russian legislation does not prevent it. This way increases profit but quality of the products intended for final consumer is decreased. Turjansky et al. (2014) confirms it.

Second determinant of ROA is assets turnover. Generally speaking, the higher the asset turnover ratio, the better the company is performing, since higher ratios imply that the company is generating more revenue per monetary value of assets. Fast moving consumer goods, such as milk and milk products, usually have higher asset turnover ratio than other branches. The assets turnover is often lower when profit margin is higher. Table 10 indicates if there are some differences between the two regions. 


\begin{tabular}{|c|c|c|c|c|c|}
\hline S-W test & Obs & W & V & $\mathbf{z}$ & p-value \\
\hline RU & 166 & 0.97649 & 2.985 & 2.492 & 0.00635 \\
\hline V4 & 143 & 0.98395 & 1.793 & 1.32 & 0.09339 \\
\hline $\mathrm{V}-\mathrm{C}$ test & Mean & Std. Err. & Std. Dev. & \multicolumn{2}{|c|}{ [95\% Conf. Interval] } \\
\hline RU & 2.308 & 0.211 & 2.721 & 1.891 & 2.725 \\
\hline V4 & 1.032 & 0.112 & 1.335 & 0.811 & 1.252 \\
\hline \multicolumn{2}{|c|}{ Ratio $=\operatorname{sd}(\mathrm{RU}) / \mathrm{sd}(\mathrm{V} 4)$} & \multicolumn{4}{|c|}{ H0: ratio $=1 ; \mathrm{HA}$ : ratio $!=1 ; \mathrm{p}$-value $=0.0000$} \\
\hline K-S test & D & p-value & corrected & \multicolumn{2}{|c|}{ Significance $(\alpha=0.05)$} \\
\hline RU & 0.0463 & 0.72 & - & \multicolumn{2}{|c|}{-} \\
\hline V4 & -0.2874 & 0 & - & \multicolumn{2}{|c|}{$\mathrm{RU}>\mathrm{V} 4$} \\
\hline Combined & 0.2874 & 0 & 0 & \multicolumn{2}{|c|}{$\mathrm{RU} \neq \mathrm{V} 4$} \\
\hline
\end{tabular}

Source: Amadeus database, own calculation

Table 9: Statistical tests of profit margin (\%).

\begin{tabular}{|c|c|c|c|c|c|}
\hline S-W test & Obs & W & $\mathbf{V}$ & $\mathbf{z}$ & p-value \\
\hline RU & 190 & 0.96426 & 5.099 & 3.739 & 0.00009 \\
\hline V4 & 169 & 0.99136 & 1.113 & 0.245 & 0.4032 \\
\hline $\mathrm{V}-\mathrm{C}$ test & Mean & Std. Err. & Std. Dev. & \multicolumn{2}{|c|}{ [95\% Conf. Interval] } \\
\hline RU & 2.253 & 0.091 & 1.25242 & 2.074 & 2.432 \\
\hline V4 & 2.4023 & 0.063 & 0.818 & 2.278 & 2.527 \\
\hline \multicolumn{2}{|c|}{ Ratio $=\operatorname{sd}(\mathrm{RU}) / \mathrm{sd}(\mathrm{V} 4)$} & \multicolumn{4}{|c|}{$\mathrm{H} 0:$ ratio $=1 ; \mathrm{HA}$ : ratio $!=1 ; \mathrm{p}$-value $=0.0000$} \\
\hline K-S test & D & p-value & corrected & \multicolumn{2}{|c|}{ Significance $(\alpha=0.05)$} \\
\hline RU & 0.2192 & 0 & - & \multicolumn{2}{|c|}{$\mathrm{RU}<\mathrm{V} 4$} \\
\hline V4 & -0.0856 & 0.269 & - & \multicolumn{2}{|c|}{ - } \\
\hline Combined & 0.2192 & 0 & 0 & \multicolumn{2}{|c|}{$\mathrm{RU} \neq \mathrm{V} 4$} \\
\hline
\end{tabular}

Source: Amadeus database, own calculation

Table 10: Statistical tests of assets turnover ratio (x).

The assets turnover is significantly higher in the Central European countries. It means that Central European countries process more intensively fresh milk and produces more fresh milk products than Russian milk processors which are specialized in production of powder milk and keep higher stocks. We could verify the hypothesis about different stock management through the indicator stock turnover.

Stock turnover measures the number of times when an inventory is sold or used in a time period such as a year. A low rate may indicate a strategy when higher inventory levels occur in anticipation of rising prices or expected market shortages. Stock turnover can also differ depending on production technology. Table 11 tests the differences of stock turnover between the two regions.

Stock turnover ratio shows the different production technology and stock management in Russian milk processors. Stock turnover of Russian milk processors is significantly lower (11.48 times per year) than in Central Europe (20.33 times per year).
In European countries, the major part of the stock is fresh milk which must be used immediately. In the Russian Federatio milk powder with long storage life of one year and more plays more important role in technology of production of milk products than in Europe.

Next financial indicators, collection period and credit period, evaluate a quality of corporate debt management. The collection period measures an average period between the events when a producer sells outputs and when producer receive the payment from its customers. The shorter period has the better impact on cash flow. Table 12 compares the collection period.

The mean collection period varies between 36 and 37 days. It is slightly longer in the Central European milk processors than in the Russian Federation. However, the difference is not so big to make conclusions about different debt management.

The credit period is the time frame between the events when a producer purchases inputs 


\begin{tabular}{|c|c|c|c|c|c|}
\hline S-W test & Obs & $\mathbf{W}$ & $\mathbf{V}$ & $\mathbf{z}$ & p-value \\
\hline RU & 182 & 0.96644 & 4.613 & 3.501 & 0.00023 \\
\hline V4 & 152 & 0.97587 & 2.840 & 2.368 & 0.00895 \\
\hline $\mathrm{V}-\mathrm{C}$ test & Mean & Std. Err. & Std. Dev. & \multicolumn{2}{|c|}{ [95\% Conf. Interval] } \\
\hline RU & 11.480 & 0.517 & 6.977 & 10.460 & 12.500 \\
\hline V4 & 20.325 & 0.782 & 9.641 & 18.780 & 21.870 \\
\hline \multicolumn{2}{|c|}{ Ratio $=\mathrm{sd}(\mathrm{RU}) / \mathrm{sd}(\mathrm{V} 4)$} & \multicolumn{4}{|c|}{$\mathrm{H} 0:$ ratio $=1 ; \mathrm{HA}:$ ratio $!=1 ; \mathrm{p}$-value $=0.0000$} \\
\hline K-S test & D & p-value & corrected & \multicolumn{2}{|c|}{ Significance $(\alpha=0.05)$} \\
\hline RU & 0.4325 & 0.000 & - & \multicolumn{2}{|c|}{$\mathrm{RU}<\mathrm{V} 4$} \\
\hline V4 & 0.0000 & 1.000 & - & \multicolumn{2}{|c|}{ - } \\
\hline Combined & 0.4325 & 0.000 & 0.000 & \multicolumn{2}{|c|}{$\mathrm{RU} \neq \mathrm{V} 4$} \\
\hline
\end{tabular}

Source: Amadeus database, own calculation

Table 11: Statistical tests of stock turnover (x).

\begin{tabular}{|c|c|c|c|c|c|}
\hline S-W test & Obs & $\mathbf{W}$ & $\mathbf{V}$ & $\mathbf{z}$ & p-value \\
\hline RU & 174 & 0.96351 & 4.825 & 3.595 & 0.00016 \\
\hline V4 & 170 & 0.99402 & 0.775 & -0.581 & 0.71934 \\
\hline V-C test & Mean & Std. Err. & Std. Dev. & \multicolumn{2}{|c|}{ [95\% Conf. Interval] } \\
\hline RU & 36.410 & 1.477 & 19.477 & 33.495 & 39.324 \\
\hline V4 & 37.001 & 1.082 & 14.110 & 34.864 & 39.137 \\
\hline \multicolumn{2}{|c|}{ Ratio $=\operatorname{sd}(\mathrm{RU}) / \mathrm{sd}(\mathrm{V} 4)$} & \multicolumn{4}{|c|}{ H0: ratio $=1 ; \mathrm{HA}$ : ratio $!=1 ; \mathrm{p}$-value $=0.0000$} \\
\hline K-S test & D & p-value & corrected & \multicolumn{2}{|c|}{ Significance $(\alpha=0.05)$} \\
\hline RU & 0.1511 & 0.020 & - & \multicolumn{2}{|c|}{$\mathrm{RU}<\mathrm{V} 4$} \\
\hline V4 & -0.1013 & 0.171 & - & \multicolumn{2}{|c|}{-} \\
\hline Combined & 0.1511 & 0.039 & 0.030 & \multicolumn{2}{|c|}{$\mathrm{RU} \neq \mathrm{V} 4$} \\
\hline
\end{tabular}

Source: Amadeus database, own calculation

Table 12: Statistical tests of collection period (days).

and when the producer's payment is due. It should be longer to positively change cash flow. The credit period is a good picture of relationship between milk processors and their suppliers (cattle farmers). Table 13 describes the results of credit period testing.

Credit period depends on the relationship between milk processors and milk producers. If there is a strong position of milk processors towards milk producers (farmers), milk processors can afford to keep longer credit period. However, if the milk processor is a cooperative of milk producers, the credit period should be shorter. Like collection period, credit period is longer in the Central European companies than in the Russian Federation.

When Russian milk producers do not manage their cash inflows and outflows carefully, their money could be devalued quickly due to the economic conditions, high inflation and increasing fuel prices. For instance, an agricultural company can buy more fuel if it is paid right away than in case of big delay. Many companies prefer to work under prepayment conditions as well when providing goods, works and services. It explains the big role of short credit in the Russian Federation. Additionally, the culture of good relations intended for long term cooperation between producers and milk processors is missing as a rule.

Next two indicators measure the short term solvency of the milk processors. Current ratio (Table 14) and liquidity ratio (Table 15) reflects the net working capital management of the companies. The current ratio expresses how many times the current liabilities are covered by short-term current assets.

There is no statistically significant difference of current ratio between the Central European countries and the Russian Federation. It means that milk processors in both regions have the same strategy of net working capital management. The mean values are above 1.1 which is below the recommended interval for industrial companies (1.6 - 2.5, Kislingerová et al., 2007). However, the milk industry generally has lower liquidity 


\begin{tabular}{|c|c|c|c|c|c|}
\hline S-W test & Obs & W & $\mathbf{V}$ & $\mathbf{z}$ & p-value \\
\hline RU & 155 & 0.94374 & 6.733 & 4.331 & 0.00001 \\
\hline V4 & 158 & 0.97353 & 3.221 & 2.659 & 0.00392 \\
\hline V-C test & Mean & Std. Err. & Std. Dev. & \multicolumn{2}{|c|}{ [95\% Conf. Interval] } \\
\hline RU & 27.898 & 1.160 & 14.437 & 25.608 & 30.189 \\
\hline V4 & 31.306 & 0.784 & 9.858 & 29.757 & 32.855 \\
\hline \multicolumn{2}{|c|}{ Ratio $=\operatorname{sd}(\mathrm{RU}) / \mathrm{sd}(\mathrm{V} 4)$} & \multicolumn{4}{|c|}{$\mathrm{H} 0:$ ratio $=1 ; \mathrm{HA}:$ ratio $!=1 ; \mathrm{p}$-value $=0.0000$} \\
\hline K-S test & D & p-value & corrected & \multicolumn{2}{|c|}{ Significance $(\alpha=0.05)$} \\
\hline RU & 0.2738 & 0.000 & - & \multicolumn{2}{|c|}{$\mathrm{RU}<\mathrm{V} 4$} \\
\hline V4 & -0.0777 & 0.389 & - & \multicolumn{2}{|c|}{ - } \\
\hline Combined & 0.2738 & 0.000 & 0.000 & \multicolumn{2}{|c|}{$\mathrm{RU} \neq \mathrm{V} 4$} \\
\hline
\end{tabular}

Source: Amadeus database, own calculation

Table 13: Statistical tests of credit period (days).

\begin{tabular}{|c|c|c|c|c|c|}
\hline S-W test & Obs & W & V & $\mathbf{z}$ & p-value \\
\hline RU & 152 & 0.95537 & 5.252 & 3.763 & 0.00008 \\
\hline V4 & 171 & 0.96788 & 4.183 & 3.266 & 0.00054 \\
\hline $\mathrm{V}-\mathrm{C}$ test & Mean & Std. Err. & Std. Dev. & \multicolumn{2}{|c|}{ [95\% Conf. Interval] } \\
\hline RU & 1.173 & 0.032 & 0.399 & 1.109 & 1.236 \\
\hline V4 & 1.160 & 0.036 & 0.470 & 1.089 & 1.231 \\
\hline \multicolumn{2}{|c|}{ Ratio $=\mathrm{sd}(\mathrm{RU}) / \mathrm{sd}(\mathrm{V} 4)$} & \multicolumn{4}{|c|}{$\mathrm{H} 0:$ ratio $=1 ; \mathrm{HA}$ : ratio $!=1 ; \mathrm{p}$-value $=0.0398$} \\
\hline K-S test & D & p-value & corrected & \multicolumn{2}{|c|}{ Significance $(\alpha=0.05)$} \\
\hline RU & 0.0585 & 0.577 & - & \multicolumn{2}{|c|}{ - } \\
\hline V4 & -0.1001 & 0.199 & - & \multicolumn{2}{|c|}{-} \\
\hline Combined & 0.1001 & 0.395 & 0.345 & \multicolumn{2}{|c|}{ - } \\
\hline
\end{tabular}

Source: Amadeus database, own calculation

Table 14: Statistical tests of current ratio (x).

because of the specific character of processing the perishable material - raw milk.

Table 15 presents the results of Liquidity ratio. The indicator subtracts inventories from current assets because they are the least liquid part of the working capital. So, the comparison between the current ratio and the liquidity ratio indicates the level of stocks in the company.

Liquidity ratio is higher in the Central European milk processors. Since there were no differences of current ratios, the results show the Russian milk processors have higher stocks of products. This is consistent with the conclusions formulated for stock turnover, which is significantly lower in Russian milk processors. The level of stocks and stock management is a key difference between milk processors in Central Europe and the Russian Federation.

Last indicator, solvency ratio (Table 16), depends on the capital structure of the company. It compares shareholders' funds to total assets. The higher is the indicator, the higher is the rate of company's self-financing through equity. Kislingerová (2010) concludes that companies with higher share of equity were more viable during the crisis period since they were not dependent on external capital and they did not bear the cost of debt service.

It can be concluded that Central European countries have higher share of equity in the total capital. The milk processing industry in the EU was strongly affected in the crisis period $2008-2009$ and the companies reduced the amount of bank loans.

Opposite trend has been observed in the Russian Federation. The credit boom took place in the investigated period. According to the statistics of Bank of Russia the financial crisis did not influence strongly on Russian banking. In a period $2008-2009$, an amount of provided credits was by $45 \%$ more than before crisis. In 2013 , number of provided credits was by $58 \%$ more than in 2009. Increasing of the amount of the provided creditsenablednewbankcreditfacilities anddeclining of the requirements to the credit users. 


\begin{tabular}{|c|c|c|c|c|c|}
\hline S-W test & Obs & $\mathbf{W}$ & $\mathbf{V}$ & $\mathbf{z}$ & p-value \\
\hline RU & 161 & 0.98530 & 1.818 & 1.360 & 0.08689 \\
\hline V4 & 173 & 0.96992 & 3.957 & 3.141 & 0.00084 \\
\hline $\mathrm{V}-\mathrm{C}$ test & Mean & Std. Err. & Std. Dev. & \multicolumn{2}{|c|}{ [95\% Conf. Interval] } \\
\hline RU & 0.639 & 0.022 & 0.277 & 0.596 & 0.683 \\
\hline V4 & 0.845 & 0.030 & 0.389 & 0.787 & 0.904 \\
\hline \multicolumn{2}{|c|}{ Ratio $=\mathrm{sd}(\mathrm{RU}) / \mathrm{sd}(\mathrm{V} 4)$} & \multicolumn{4}{|c|}{$\mathrm{H} 0:$ ratio $=1 ; \mathrm{HA}:$ ratio $!=1 ; \mathrm{p}$-value $=0.0000$} \\
\hline K-S test & D & p-value & corrected & \multicolumn{2}{|c|}{ Significance $(\alpha=0.05)$} \\
\hline RU & 0.2440 & 0.000 & - & \multicolumn{2}{|c|}{$\mathrm{RU}<\mathrm{V} 4$} \\
\hline V4 & 0.0000 & 1.000 & - & \multicolumn{2}{|c|}{-} \\
\hline Combined & 0.2440 & 0.000 & 0.000 & \multicolumn{2}{|c|}{$\mathrm{RU} \neq \mathrm{V} 4$} \\
\hline
\end{tabular}

Source: Amadeus database, own calculation

Table 15: Statistical tests of liquidity ratio (x).

\begin{tabular}{|c|c|c|c|c|c|}
\hline S-W test & Obs & $\mathbf{W}$ & $\mathbf{V}$ & $\mathbf{z}$ & p-value \\
\hline RU & 193 & 0.93878 & 8.855 & 5.009 & 0.00000 \\
\hline V4 & 170 & 0.99078 & 1.195 & 0.406 & 0.34247 \\
\hline V-C test & Mean & Std. Err. & Std. Dev. & \multicolumn{2}{|c|}{ [95\% Conf. Interval] } \\
\hline RU & 34.144 & 1.694 & 23.539 & 30.802 & 37.486 \\
\hline V4 & 43.424 & 1.223 & 15.949 & 41.009 & 45.839 \\
\hline \multicolumn{2}{|c|}{ Ratio $=\mathrm{sd}(\mathrm{RU}) / \mathrm{sd}(\mathrm{V} 4)$} & \multicolumn{4}{|c|}{ H0: ratio $=1 ;$ HA: ratio $!=1 ; p$-value $=0.0000$} \\
\hline K-S test & D & p-value & corrected & \multicolumn{2}{|c|}{ Significance $(\alpha=0.05)$} \\
\hline RU & 0.3383 & 0.000 & - & \multicolumn{2}{|c|}{$\mathrm{RU}<\mathrm{V} 4$} \\
\hline V4 & -0.0676 & 0.437 & - & \multicolumn{2}{|c|}{-} \\
\hline Combined & 0.3383 & 0.000 & 0.000 & \multicolumn{2}{|c|}{$\mathrm{RU} \neq \mathrm{V} 4$} \\
\hline
\end{tabular}

Source: Amadeus database, own calculation

Table 16: Statistical tests of solvency ratio (\%).

\section{Conclusion}

The aim of the article is to compare financial performance of the Central European (V4) and Russian milk processors in the period 2008 - 2013. It covers the period before the Russian embargo. The Russian Federation has been a net importer of milk and milk products. However, it attempts to increase the self-sufficiency in agricultural commodities and food products.

The analysis revealed significantly higher profitability of Russian milk processors. The big gap in ROCE is a consequence of different capital structure of the Russian and the Central European milk processor. Russian milk processors use significantly higher share of long-term debt and loans to shareholder funds. The main reason is that the financial crisis did not appear in the Russian Federation to such an extent as in Central Europe. So, the Russian milk processors have continuously increased the bank loans in that period. Alternatively, the use of debt in the Central European countries was sharply reduced in the crisis period and Central European milk processors had better solvency than Russian companies.

Overall, the profitability measured by ROA was significantly higher in the Russian Federation than in Central Europe. It was caused by higher profit margin of Russian milk processors. The main reason of higher profit margin is different cost management in Russian milk processors who buy fresh milk at low price from farmer and use cost-cutting technology of milk processing. However, it has negative impact on quality of Russian milk products which has been frequently discussed issue. The specific features of milk production establish different stock turnover ratio which is significantly lower in the Russian Federation.

Concerning debt management, Russian milk processors had shorter credit period than the Central European companies. It is caused by the fact that many companies in the Russian Federation prefer to work under prepayment conditions as well when 
providing goods, works and services.

Finally, the analysis did not prove any significant difference in liquidity expressed by current ratio. It means that milk processors in both regions have the same strategy of net working capital management. However, liquidity ratio that does not take into account inventories is significantly lower in the Russian Federation as a consequence of different stock management between the two regions. The skimmed milk powder which is used more by Russian milk processors for production of milk products requires different stock management than fresh milk.

The opportunity for next research would be the impact analysis of increasing self-sufficiency of the Russian Federation and the Russian embargo on financial management strategy of the Central European and Russian milk processors. However, the effects can be analysed when the sufficient number of financial statements will be available.

\section{Acknowledgements}

The article was supported by the institutional support of the University of Economics, Prague, project no. VŠE IP300040. The authors would like to enclose gratitude to Sheiko Irina and Head of Finance Department of Russian State Agrarian Academy Kostina Raisa for help in consulting.

Corresponding author:

Doc. Ing. Jindřich Špička, Ph.D.

Faculty of Business Administration, University of Economics

W. Churchill Sq. 1938/4, 13067 Prague, Czech Republic

Phone: 0042022409 8650,Email: jindrich.spicka@vse.cz

\section{References}

[1] Alborov, R., Kontsevaya and S., Livenskaya, G. (2012) "Improvement of cost and management accounting in milk processing companies", Accounting in Agriculture (Бухучет в сельском хозяйстве), Vol. 10, pp. 70-74. ISSN 2075-0250.

[2] Buys, L., Mengersen, K., Johnson, S., van Buuren, N. and Chauvin, A. (2014) "Creating a Sustainability Scorecards a predictive tool for measuring the complex social, economic and environmental impacts of industries, a case study: Assessing the viability and sustainability of the dairy industry", Journal of Environmental Management, Vol. 133, January 15, pp.184-192. ISSN 0301-4797.

[3] Donnellan, T., Keane, M. (2015) “The European Dairy Sector in a new Era", Proceedings of the Conference Agrarian perspectives XXIII, Prague, pp. 5-19. ISBN 978-80-213-2581-4.

[4] Doubek, V., Švasta, J. and Blažková, L. (2012) “Agricultural trade on the example of milk from the perspective of the multi-criteria analysis", Agricultural Economics, Vol. 58, No. 7, pp. 315-323. ISSN 0139-570X.

[5] Foltínová, A. and Špička, J. (2014) "The use of controlling in agricultural enterprises and their competitiveness", Agricultural Economics, Vol. 60, No. 7, pp. 314-322. ISSN 0139-570X.

[6] Gulaeva, T. and Trystsina, N. (2010) "The condition and development prospects of dairy cattle breeding and dairy market”, Vestnik OrelGAU (Вестник ОрелГАУ), Vol. 5, No. 6, pp. 81-85. ISSN 1990-3618.

[7] Chloupková, J., Svendsen, G. and Svendsen, G. (2003) "Building and destroying social capital: The case of cooperative movements in Denmark and Poland", Agriculture and Human Values, Vol. 20, No. 3, pp. 241-252. ISSN 0889-048X.

[8] Kislingerová, E., (2010) "Podnik v časech krize (Company in the times of crisis)", 1 st ed. Prague: Grada Publishing. ISBN 978-80-247-3136-0.

[9] Kislingerová, E. Boukal, P., Čepelka, V., Hnilica, J., Novotný, J., Scholleová, H., Sieber, P. and Vávrová, H. (2007) "Manažerské finance (Managerial finance)", Praha: C. H. Beck. ISBN 978-80-7179-903-0. 
[10] Kostina, R. (2009) "Methodology of controlling and analysis in managerial decisions in agricultural holdings", Moscow: RGAY-MSHA name Timiryazev. ISBN 978-5-9675-0292-7..

[11] Petrick, M. (2015) "The prospects for Russian food self-sufficiency", $29^{\text {th }}$ International Conference of Agricultural Economists in Milan, 11 August. [Online]. Available at http://www.iamo.de/ fileadmin/user_upload/Bilder_und_Dokumente/06-veranstaltungen/icae-mailand_2015/ICAE_ symposion_Martin_Petrick/03_Petrick.pdf [Accessed: 5 December 2015].

[12] Mejstř́iková, L. and Mezera, J. (2011) "Positive and Negative Aspects of Financial Economic Development in Dairy Industry in the CR in 2007-2009 as Revealed by Spider Analysis and Economic Value Added", Proceedings of the Conference Agrarian perspectives XX, Prague, pp. 99-106. ISBN 978-80-213-2196-0.

[13] Perekhozhuk, O., Hockmann, H., Bakucs, Z. and Ferto, I. (2011) "Identification of market power in the Hungarian dairy industry: a plant-level analysis", International Congress European Association of Agricultural Economists, August 30-September 2, 2011, Zurich, Switzerland.

[14] Ratinger, T. and Bošková, I. (2013) “Strategies and effects of milk producers' organizations in the Czech Republic", Agricultural Economics, Vol. 59, No. 3, pp. 113-124. ISSN 0139-570X.

[15] Royston, P. (1992) “Approximating the Shapiro-Wilk W-test for non-normality", Statistics and Computing, Vol. 2, No. 3, pp. 117-119. ISSN 0960-3174.

[16] Rozsa, A. (2014) "Financial performance analysis and bankruptcy prediction in hungarian dairy sector", Annals of the University of Oradea: Economic Science, Vol. 23, No. 1, pp. 938-947. ISSN 1222-569X.

[17] Shapiro, S. S. and Wilk, M. B. (1965) "An analysis of variance test for normality (complete samples)", Biometrika, Vol. 52, No. 3-4, pp. 591-611. ISSN 0006-3444.

[18] Stephenson, M. W. (2006) "Financial Performance and Other Characteristics of On-Farm Dairy Processing Enterprises in New York, Vermont and Wisconsin", Research Bulletins No. 121583, Cornell University, Department of Applied Economics and Management.

[19] Svatoš, M., Smutka, L. and Ishchukova, N. (2014) "The position of agriculture in the Russian Federation - the last two decades development overview”, Agricultural Economics, Vol. 60, No. 11, pp. 489-502. ISSN 0139-570X.

[20] Špička, J. (2015) “The efficiency improvement of Central European corporate milk processors in 2008 - 2013”, Agris on-line Papers in Economics and Informatics, Vol. 7, No. 4, pp. 175-188. ISSN 1804-1930.

[21] Bureau van Dijk. (2015) “Amadeus User Guide - Ratios”. Bureau van Dijk, Nov. 2015. [Online]. Available: https://amadeus.bvdinfo.com/ [Accessed: 12 Nov. 2015, for registered users only].

[22] CLAL. (2015) "Dairy by country”. CLAL - Italian Dairy Economic Consulting, Nov. 2015. [Online]. Available: http://www.clal.it/en/?section=stat_ue15 [Accessed: 1 Nov. 2015].

[23] Eurostat (2015) ,Structural business statistics - annual detailed enterprise statistics for industry (NACE Rev. 2, B-E) - Manufacture of dairy products". Eurostat, Nov. 2015. [Online]. Available: http://appsso.eurostat.ec.europa.eu/nui/show.do [Accessed: 1 Nov. 2015].

[24] Federal State Statistics Service of the Russian Federation (2015) "Russia in figures", Federal State Statistics Service of the Russian Federation, Nov. 2015. [Online]. Available: www.gks.ru [Accessed: 5 Nov. 2015]. 